\title{
CZECH FLUID SULFOCALCIC ASH AND FLY ASH
}

\author{
"FRANTIŠEK ŠKVÁRA*, ROSTISLAV ŠULC**, ROMAN SNOP***, ZUZANA ZLÁMALOVÁ CÍLOVÁ*, \\ ADÉLA PETEROVÁ*, LUBOMÍR KOPECKÝ****, PETR FORMÁČEK** \\ *Department of Glass and Ceramics, Faculty of Chemical Technology, University of Chemistry and Technology Prague \\ **Department of Building Technology, Faculty of Civil Engineering, Czech Technical University in Prague \\ ***CEZ Group, Energetic Products Ltd., Hostivice \\ ****Department of Mechanics, Faculty of Civil Engineering, Czech Technical University in Prague \\ ${ }^{\#}$ E-mail: Frantisek.Skvara@vscht.cz
}

Submitted June 9, 2016; accepted July 29, 2016

\begin{abstract}
Keywords: Fluid sulfocalcic ash, Fly ash, Hydration of ashes
Sulfocalcic ash is formed during the fluidized bed combustion of coal in the presence of limestone. It differs from classical fly ash by its composition and properties. Sulfocalcic ash contains free $\mathrm{CaO}, \mathrm{CaSO}_{4}$ and partially sintered aluminosilicates. In contact with water, it produces $\mathrm{Ca}(\mathrm{OH})_{2}$, expansive ettringite and a small amount of the CSH phase. There is little information about these ashes in the literature. At present, the possibility of using fluid sulfocalcic ashes is quite limited because of the formation of expansive ettringite. More research in the field of sulfocalcic ashes is a necessity because increasing quantities of this product are rejected by the energy-generation industry.
\end{abstract}

\section{INTRODUCTION}

Energetic products

The generation of the electric power by combustion of coal and the subsequent desulfurization of flue gases give rise to fly ashes, gypsum and fluidized-bed fly ashes. The volume of these products produced all over the world is huge. Fly ash is formed during the combustion of coal at temperatures exceeding $950^{\circ} \mathrm{C}$ (frequently above $\left.1100^{\circ} \mathrm{C}\right)$. The gypsum $\left(\mathrm{CaSO}_{4} \cdot 2 \mathrm{H}_{2} \mathrm{O}\right)$ mostly originates as a product of flue gas desulfurization processes based on washing by limestone. The two above mentioned materials have attracted a rather considerable attention as this is shown by published literature. The fly ash rejected during the fluidized-bed combustion of coal represents another product. The fluidized-bed combustion of coal in the Czech Republic as well as in some other countries is combined with the flue gas desulfurization by mixing pulverized coal with pulverized limestone. About 1.5 million tons of this type of fly ash is produced in the Czech Republic annually. Particles of fluidized-bed ash (called „Fluidized-bed ash and fluidized-bed fly ash for building trade applications" by the Czech standard CSN 72 2080) represent essentially solid residues arising during the fluidized-bed combustion of coal, a mixture of mineral components in coal and the desulfurization products resulting from reactions of sorbents (for in- stance, limestone or dolomite) with sulfur dioxide (their formation temperature does not exceed $850^{\circ} \mathrm{C}$ ). However, different interpretations of the term ,fluidizedbed fly ash" can be found in the technical literature (Table 1). In contrast to the fly ash, the fluidized-bed fly ash (according to the Czech standard CSN 72 2080) contains $\mathrm{CaSO}_{4}$; therefore, the term „sulfocalcic ash“" is more suitable for its characterization.

Table 1. Fly ash terminology.

Fly ash generated during the high-temperature Fly ash combustion of coal

Fly ash generated during $\mathrm{CFBC}$ ash (circulated fluidized the fluidized bed bed combustion) combustion of coal FBC ash (fluidized bed combustion)

Fly ash occurring during Partially sulfated CFBC ash the fluidized bed Dry flue gas desulfurization product combustion of coal Soil shale CFBC ash with limestone Sulfocalcic ash

Product - a residue on

the grate bar during $\quad$ CFBC spent bed material

the fluidized bed

CFBC bottom ash

combustion of coal 
Mechanism of sulfocalcic ash formation

Two basic reactions take place during the combustion of pulverized coal and limestone at temperatures ranging from 800 to $950^{\circ} \mathrm{C}$ :

$$
\mathrm{CaCO}_{3} \rightarrow \mathrm{CaO}+\mathrm{CO}_{2} \quad \mathrm{CaO}+\mathrm{SO}_{2}+1 / 2 \mathrm{O}_{2} \rightarrow \mathrm{CaSO}_{4}
$$

The above processes are accompanied by limestone decomposition and the subsequent $\mathrm{CaO}$ sulfatization. The final product contains $\mathrm{CaSO}_{4}$ (on the surface of the particles) and $\mathrm{CaO}$ (inside the particles) [1]. According to this idea, $\mathrm{CaSO}_{4}$ particles surround $\mathrm{CaO}$ particles (pseudomorphoses from $\mathrm{CaCO}_{3}$ ). $\mathrm{A} \mathrm{CaSO}_{4}$ layer forms around $\mathrm{CaO}$ if the $\mathrm{CaCO}_{3}$ particle is compact. However, the sulfatization process is almost accomplished if the $\mathrm{CaCO}_{3}$ particle presents fissures; in this case, the particles in question contain minimum $\mathrm{CaO}$ (Figure 1).
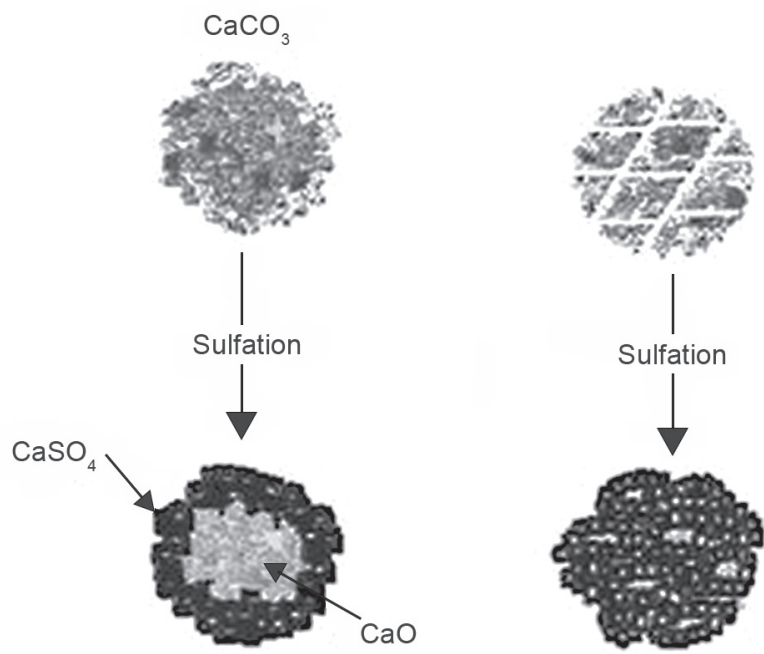

Figure 1. Hypothetical representation of limestone sulfatization at higher temperatures [1]

The combustion product is composed of a chemically heterogeneous mixture. $\mathrm{CaSO}_{4}$ is present in the mixture in the form of high-temperature anhydrite $\mathrm{AII}, \mathrm{CaO}$ as well as partially sintered alumino-silicate particles originating from incombustible coal components that have been subjected to dehydration or decarbonization during the combustion and which, eventually, sinter partially. In contrast to the fly ashes, no vitreous (liquid) phase arises during the combustion. However, a transformation into partially sintered products containing $\mathrm{Si}, \mathrm{Al}, \mathrm{Fe}$ and other elements takes place. In dependence on the coal composition, the product can also contain a variety of other minerals as, for example, quartz and hematite. Also the reaction products of $\mathrm{CaO}$ with incombustible parts of coal containing $\mathrm{Si}$ and $\mathrm{Al}$ minerals can be detected in the sulfocalcic fly ash. In this case, the formation of $\mathrm{Ca}$ silicates, aluminates and ferrites can take place to some extent.
A part of the sulfocalcic fluidized-bed fly ash drops to the grate bar of the combustion boiler where the particles conglomerate by giving rise to a denser product - bed fly ash.

There is a variety of standards devoted to fly ash and delimiting its composition. The standards specify limits for the $\mathrm{SiO}_{2}$ content, the content of active $\mathrm{SiO}_{2}(\mathrm{CSN}$ EN 197-1), the $\mathrm{CaO}$ content (CSA A3001) and the $\mathrm{SiO}_{2}+$ $+\mathrm{Al}_{2} \mathrm{O}_{3}+\mathrm{Fe}_{2} \mathrm{O}_{3}$ content (ASTM C 618). All standards are quite strict as regards the $\mathrm{SO}_{3}$ content -3 to $5 \%$ at the maximum.

The sulfocalcic fly ash does not meet the requirements specified in the above standards and, therefore, its application in the concrete production has not been permitted yet. No specific criteria for sulfocalcic (fluidized-bed) fly ash has been mentioned in the technical literature so far. Only Anthony et al [2] suggest the following mass criteria for the characterization of this type of fly ashes:

$$
\frac{\mathrm{SiO}_{2}+\mathrm{Al}_{2} \mathrm{O}_{3}}{\mathrm{CaO}_{\text {total }}+\mathrm{SO}_{3}} \text { and } \frac{\text { freeCaO }}{\mathrm{SO}_{3}}
$$

The above criteria may be applied to the assessment of properties of sulfocalcic fly ashes.

\section{Sulfocalcic ash analogy}

In addition to sulfocalcic ashes produced in the Czech Republic there are similar sulfocalcic products occurring abroad. Products having compositions similar to (but not identical with) that of fluidized-bed fly ashes produced in the Czech republic are rejected in Canada during the desulfurization of flue gases from the combustion of petroleum coke. Canadian fly ashes contain $11-14 \% \mathrm{SiO}_{2}, 5-6 \% \mathrm{Al}_{2} \mathrm{O}_{3}, 36-43 \% \mathrm{CaO}$, $10-22 \%$ free $\mathrm{CaO}$ and $1-2 \% \mathrm{~V}_{2} \mathrm{O}_{5}$. The range of particle sizes is rather wide: coarse-grained particles larger than $100 \mu \mathrm{m}$ predominate (the specific surface area BET ranging from $\left.1.2-4.7 \mathrm{~m}^{2} \cdot \mathrm{g}^{-1}\right)$. The Canadian sulfocalcic fly ash possesses the tendency to harden but its volume is not stable after hardening. The fly ash is also sensitive to air moisture. The zonal character of particles is obviously due to the presence of vanadium oxide. The outer jacket of the particles is formed predominantly by $\mathrm{CaSO}_{4}$, deeper layers are constituted of a mixture of $\mathrm{CaSO}_{4}$ with $\mathrm{CaO}$ while the core is pure $\mathrm{CaO}$ [3]. Other sulfocalcic fluidized-bed products similar to fly ashes occurring during the desulfurization in the Czech Republic can be found in Estonia and Israel where they are produced during the combustion of oil-containing shales without desulfurization $[4,5]$. These products are characterized by a high content of $\mathrm{CaO}(30-53 \%)$, free $\mathrm{CaO}(10-25 \%)$ and $\mathrm{CaSO}_{4}(1-10 \%)$. The products in question are prone to harden but their volume is not stable after hardening. 


\section{EXPERIMENTAL}

The chemical composition of fly ashes was determined with the aid of the XRF analysis - spectrometer ARL 9400 XP (Thermo ARL, Switherland) while the XRD diffraction analysis - diffractometer PANanalytical X'Pert PRO(PANanalytical, Holland) with the PDF 2 database was applied to the determination of the mineralogical composition. As regards the sulfocalcic fly ashes, their chemical composition was complemented by the determination of the free $\mathrm{CaO}$ content by using a method described in the Czech standard CSN P 72208. The fly ashes were further characterized by data obtained during the determination of the particle size distribution with the aid of the apparatus Mastersizer 2000 MU (Malvern Instruments Ltd., UK) as well as by porosity data obtained by $\mathrm{Hg}$ porosimetry AutoPore III (Micromeritics, USA). The character of fly ash particles was monitored with the aid of SEM comprising an EDX point-by-point analysis (Hitachi S4700, Japan). Fly ashes were used for preparation of the slurries (water coefficient ranging from 0.3 to 1.0 ) that were characterized by values obtained during the determination of their "standard" consistency according to the procedure described in Czech standards CSN 72 2071 and CSN 72 2080. The hydration process of the slurries was investigated by monitoring the release of the hydration heat in an isothermal calorimeter (TAM Air, TA Instruments, USA). The volume changes of the slurries that were taking place taking place during the hydration were determined by measuring directly length variations of experimental bodies with the dimensions of $4 \times 4 \times 16 \mathrm{~cm}$ (gauge blocks were used for this purpose). The hydration products were characterized with the aid of a scanning electron microscope (SEM) with a pointby-point analysis (Hitachi S4700).

\section{RESULTS AND DISCUSSION}

Fly ash composition

Fly ashes from CEZ power plants were used for investigation, i.e. fly ashes and sulfocalcic ones occurring during the fluidized-bed combustion of coal mixed with limestone (flue gas desulfurization processes). The chemical composition of sulfocalcic fly ashes is given in Tables 2 to 4 .

Table 2. Composition of fluidized-bed sulfocalcic fly ashes (XRF).

\begin{tabular}{lrrrrr}
\hline \multirow{2}{*}{ Oxide } & \multicolumn{5}{c}{$w[\%]$} \\
\cline { 2 - 6 } & FK11 Ú & FK11 LP & FK12 ÚP & FK12 LP & ETH 10 \\
\hline $\mathrm{Al}_{2} \mathrm{O}_{3}$ & 32.31 & 30.30 & 29.76 & 26.93 & 28.84 \\
$\mathrm{SiO}_{2}$ & 38.99 & 37.36 & 35.44 & 32.01 & 34.30 \\
$\mathrm{SO}_{3}$ & 4.99 & 7.44 & 6.07 & 7.29 & 7.69 \\
$\mathrm{CaO}$ & 8.84 & 13.68 & 14.81 & 22.56 & 16.51 \\
$\mathrm{Fe}_{2} \mathrm{O}_{3}$ & 5.45 & 3.31 & 5.41 & 3.45 & 4.56 \\
$\mathrm{TiO}_{2}$ & 7.12 & 5.85 & 6.10 & 5.83 & 5.96 \\
\hline
\end{tabular}

Table 3. Composition of fly ashes (XRF).

\begin{tabular}{lrrr}
\hline \multirow{2}{*}{ Oxide } & \multicolumn{3}{c}{$w[\%]$} \\
\cline { 2 - 4 } & Silo A & \multicolumn{1}{c}{$\mathrm{S} 1$} & \multicolumn{1}{c}{$\mathrm{S} 2$} \\
\hline $\mathrm{Al}_{2} \mathrm{O}_{3}$ & 35.55 & 35.60 & 35.32 \\
$\mathrm{SiO}_{2}$ & 51.63 & 52.08 & 52.13 \\
$\mathrm{SO}_{3}$ & 0.24 & 0.26 & 0.25 \\
$\mathrm{CaO}$ & 1.98 & 1.92 & 1.91 \\
$\mathrm{Fe}_{2} \mathrm{O}_{3}$ & 5.15 & 4.72 & 4.90 \\
$\mathrm{TiO}_{2}$ & 1.79 & 1.76 & 1.74 \\
\hline
\end{tabular}

Table 4. Concentrations of free $\mathrm{CaO}$ in fluidized-bed sulfocalcic fly ashes.

\begin{tabular}{lc}
\hline Sulfocalcic fly ash & $\mathrm{CaO}_{\text {free }}[\%]$ \\
\hline FK12 ÚP & 7.6 \\
FK12 LP & 8.8 \\
ETH 10 & 6.9 \\
\hline
\end{tabular}

Sulfocalcic fly ashes of Czech provenience contain predominantly $35-42 \% \mathrm{SiO}_{2}, 30-35 \% \mathrm{Al}_{2} \mathrm{O}_{3}, 3-7 \%$ $\mathrm{Fe}_{2} \mathrm{O}_{3}, 5-8 \% \mathrm{SO}_{3}$ and $5-10 \%$ free $\mathrm{CaO}$ (Tables 2 and 3 ). In contrast to sulfocalcic fly ashes, the fly ashes are characterized by a substantially lower $\mathrm{SO}_{3}$ content; furthermore, they do not contain any free $\mathrm{CaO}$.

Grain size distribution of fly ashes

Differences in the grain size distributions of fly ashes and sulfocalcic ones are evident from Figure 2 and 3 as

Table 5. Parameters of grain size distribution for sulfocalcic fly ashes.

\begin{tabular}{lcccc}
\hline Fly ash & FK11 ÚP & FK12 ÚP & ETH10 & ETH20 \\
\hline $\mathrm{d}_{63.8}[\mu \mathrm{m}]$ & 36.7 & 36.3 & 28.9 & 26.6 \\
$\mathrm{~d}_{50}[\mu \mathrm{m}]$ & 27.1 & 23.0 & 15.2 & 16.1 \\
\hline
\end{tabular}

Table 6. Parameters of grain size distribution for fly ashes.

\begin{tabular}{lcccc}
\hline Fly ash & Silo A & S1 & S2 & K9 \\
\hline $\mathrm{d}_{63,8}[\mu \mathrm{m}]$ & 42.9 & 41.0 & 32.9 & 35.7 \\
$\mathrm{~d}_{50}[\mu \mathrm{m}]$ & 28.9 & 27.6 & 20.7 & 24.6 \\
\hline
\end{tabular}

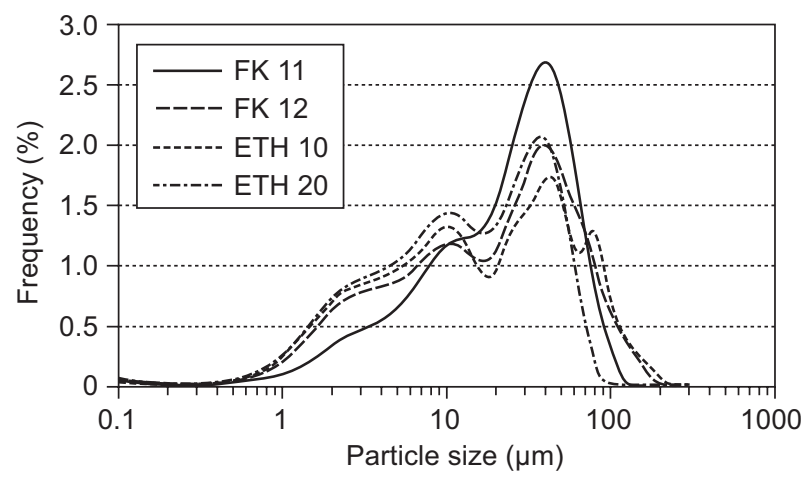

Figure 2. Grain size distribution of fluidized-bed sulfocalcic fly ash. 


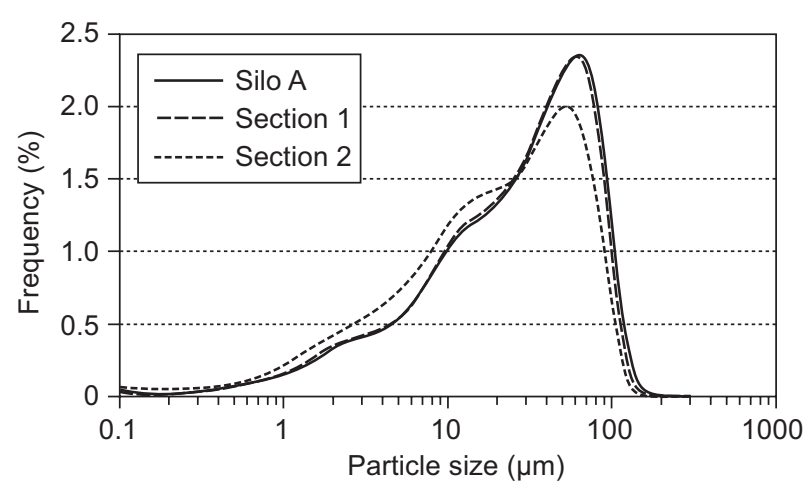

Figure 3. Grain size distribution of fly ash.

well as from Tables 5 and 6 . Sulfocalcic fly ashes rather represent a mixture of two fractions. On the contrary, the fly ashes are characterized by a monodispersed system of grain sizes.

\section{Mineralogical composition of fly ashes}

Mineralogical compositions of sulfocalcic and ordinary fly ashes differ substantially. This fact is due to the different temperatures of their origin $\left(850^{\circ} \mathrm{C}\right.$ for sulfocalcic fly ashes as compared to more than $950^{\circ} \mathrm{C}$ for the ordinary ones). The sulfocalcic fly ash contains crystalline phases of $\mathrm{CaSO}_{4}, \mathrm{CaO}$ as well as coal residues (hematite, quartz). The X-ray diffraction does not show any presence of $\mathrm{Si}$ and $\mathrm{Al}$ compounds because of their amorphous character. $\mathrm{CaSO}_{4}$ is present in the form of high-temperature anhydrite AII that occurs in two forms - as an insoluble (PDF 00-037-1496) and soluble (PDF 00-003-0162) compound. However, it is difficult to distinguish between these AII forms in sulfocalcic fly ashes. In addition to a vitreous (amorphous) phase (a broad diffusion peak) the ordinary fly ashes also contain minerals present in the coal or minerals formed during the combustion process as quartz, mullite, hematite, etc.

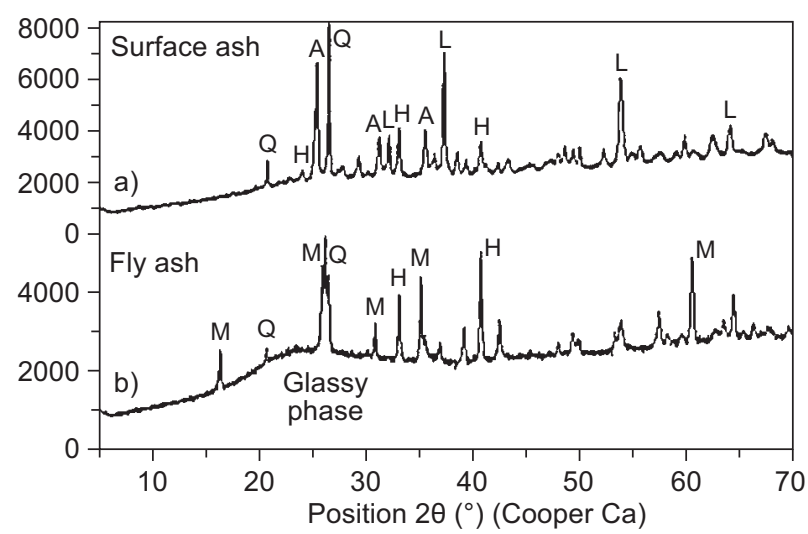

Figure 4. Diffractograms of fly ashes a) fluidized-bed sulfocalcic fly ash; b) ordinary fly ash $\left(\mathrm{A} . . . \mathrm{CaSO}_{4}\right.$ anhydrite II, L...CaO, Q... $\mathrm{SiO}_{2}, \mathrm{H}$...hematite, Q...quartz, M...mullite).
Fly ash morphology

The morphology of sulfocalcic fly ashes and that of the ordinary ones differs because of the different temperatures existing during the combustion process. No melt forms in sulfocalcic fly ashes because of lower combustion temperatures (mostly below $850^{\circ} \mathrm{C}$ ) and only a sintering process takes place. The character of sulfocalcic fly ashes is evident from pictures taken with the aid of a scanning electron microscope (Figure 5).

Sulfocalcic fly ashes contain predominantly $\mathrm{CaSO}_{4}$, $\mathrm{CaO}$ as well as $\mathrm{Al}$ and $\mathrm{Si}$ compounds occurring as residues of incombustible materials present in the coal (Figure 5). Furthermore, there are also other minerals as quartz and hematite the presence of which is dependent on the coal composition. $\mathrm{CaO}$ present in sulfocalcic fly ashes exhibits morphology similar to that observed in softly calcined lime. Residues of layered structures of dehydrated and partially sintered argillaceous minerals are also present in sulfocalcic fly ashes. Their morphology and composition correspond to a metastable product formed during the firing of kaolinite (meta-kaolin).

The data obtained with the aid of high-pressure mercury intrusion porosimetry indicate that the particles

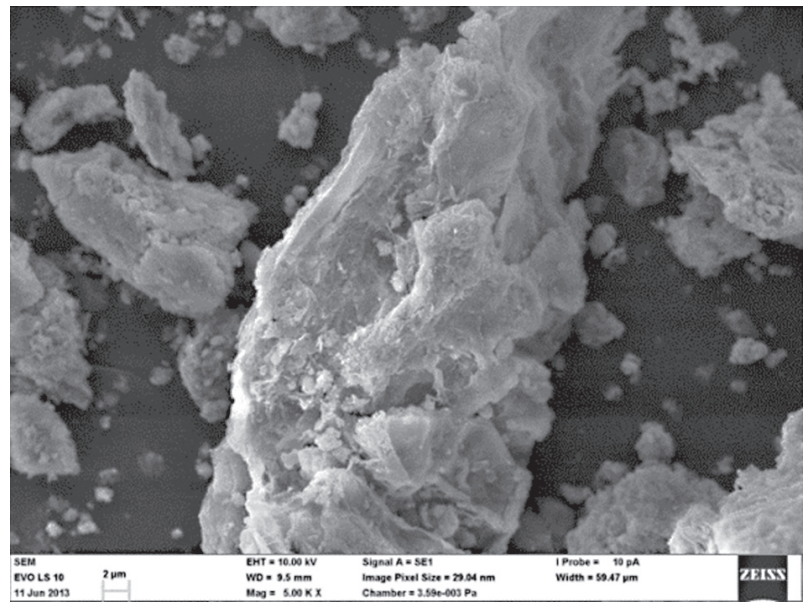

a)

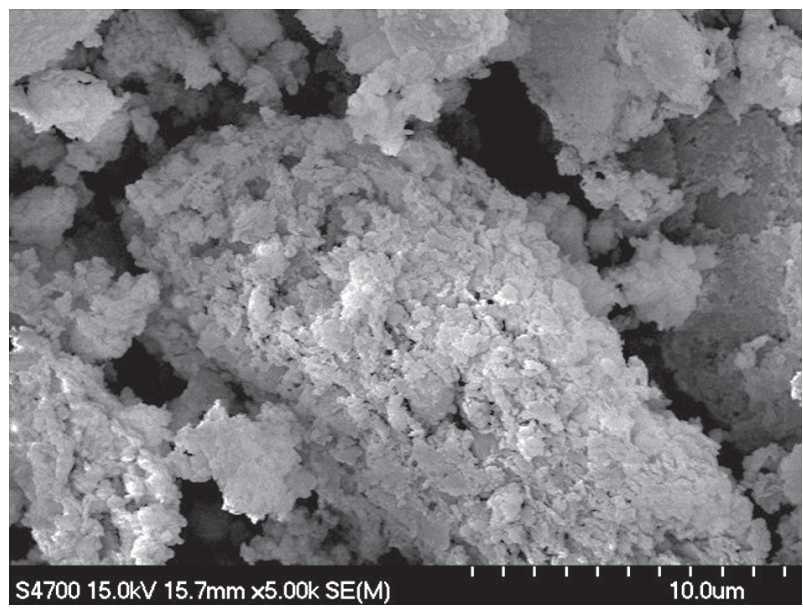

b)

Figure 5. SEM pictures of sulfocalcic fly ashes. 
of sulfocalcic fly ashes are porous (Figure 7). The pores with a size of the order of micrometers occupy the largest volume. This is not the porosity in the true sense of the word because the particles aggregate to form clusters (Figure 5 and 6). Moreover, even the porosity of the layer formed by packed particles makes itself felt during the determination of this parameter with the aid of the mercury intrusion porosimetry. The porosity of sulfocalcic fly ashes is evidently interrelated with the $\mathrm{CaO}$ porosity (pseudo-morphoses from $\mathrm{CaCO}_{3}$ ) and that of aluminosilicate clusters.

Particles of sulfocalcic fly ashes (BET analysis) possess a relatively large specific surface area (Table 7).

The morphology of fly ashes is rather manifold $[6,7]$. The ordinary fly ash is a vitreous material containing predominantly $\mathrm{Si}, \mathrm{Al}, \mathrm{Ca}, \mathrm{Fe}$ as well as a variety of other

Table 7. Specific surface area (BET) of sulfocalcic fly ashes.

\begin{tabular}{lc}
\hline Sulfocalcic fly ash & BET \\
\hline ETH 20 & $12.51 \mathrm{~m}^{2} \mathrm{~g}^{-1}$ \\
FK 12 & $8.09 \mathrm{~m}^{2} \mathrm{~g}^{-1}$ \\
\hline
\end{tabular}

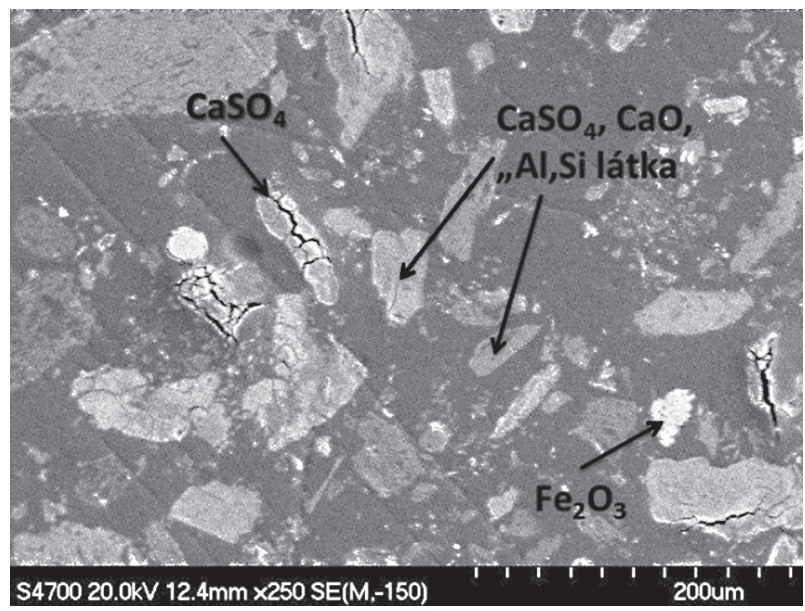

a)

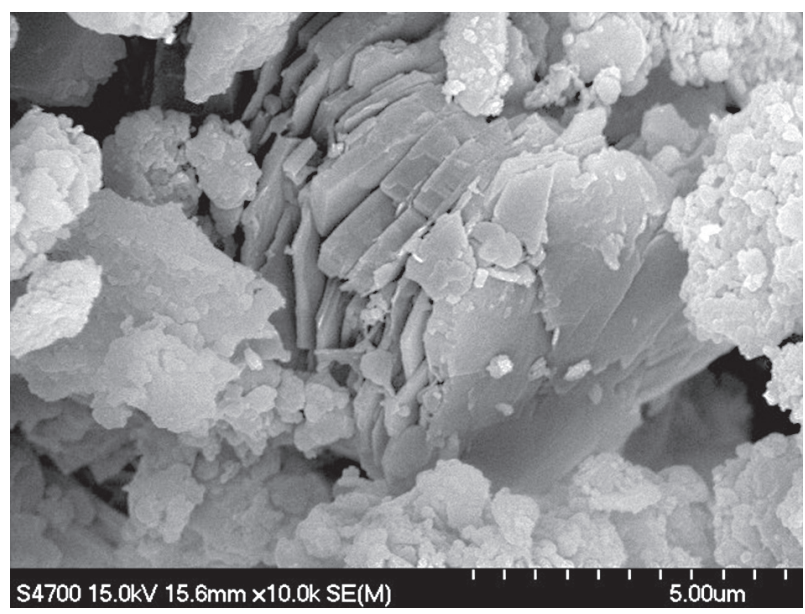

c) elements originating from incombustible components present in the coal (Figure 8). Furthermore, the fly ash also contains crystalline bodies as, for instance, quartz and mullite. The high-temperature combustion process above $950^{\circ} \mathrm{C}$ is accompanied by the formation of a melt

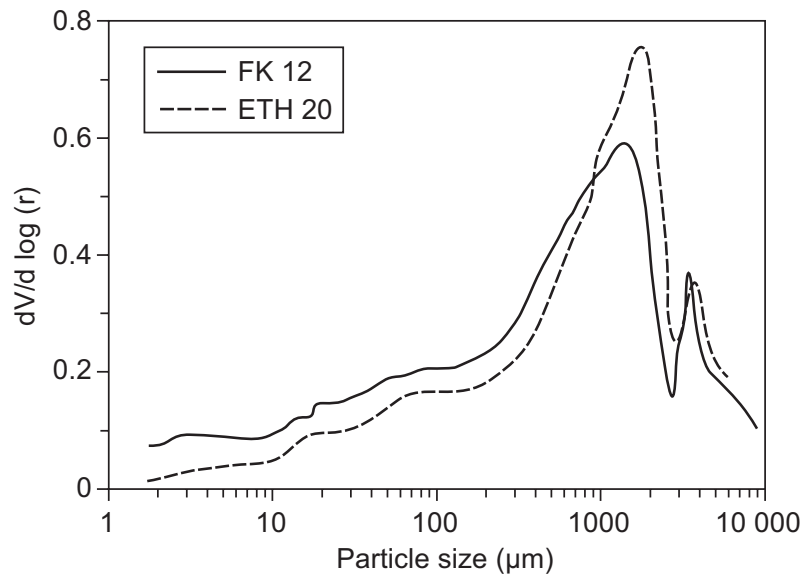

Figure 7. Pore size distribution of in sulfocalcic fly ashes from mercury intrusion porosimetry.

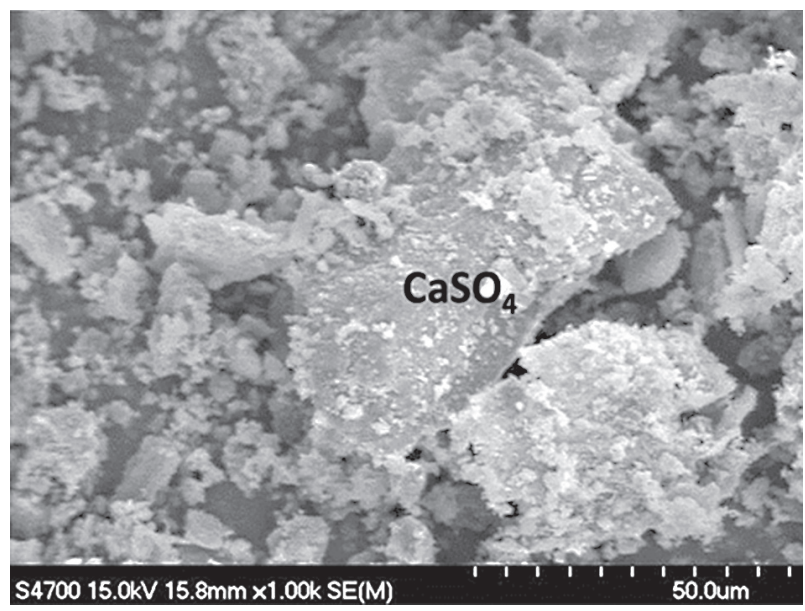

b)

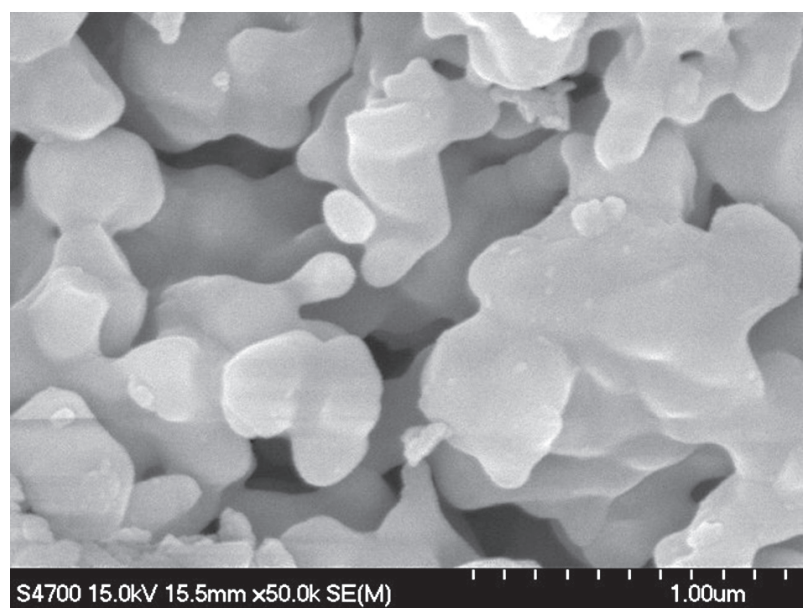

d)

Figure 6. SEM pictures of the sulfocalcic fly ash: a) thin section; b) $\mathrm{CaSO}_{4}$; c) layered amorphous structure of a $\mathrm{Si}$, $\mathrm{Al}$ compound similar to that of metakaolin; d) $\mathrm{CaO}$. 


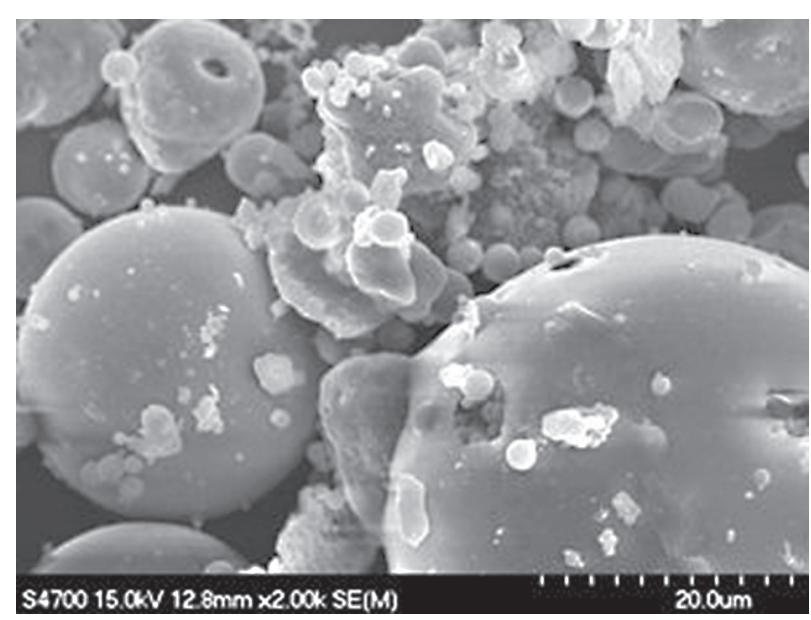

a)

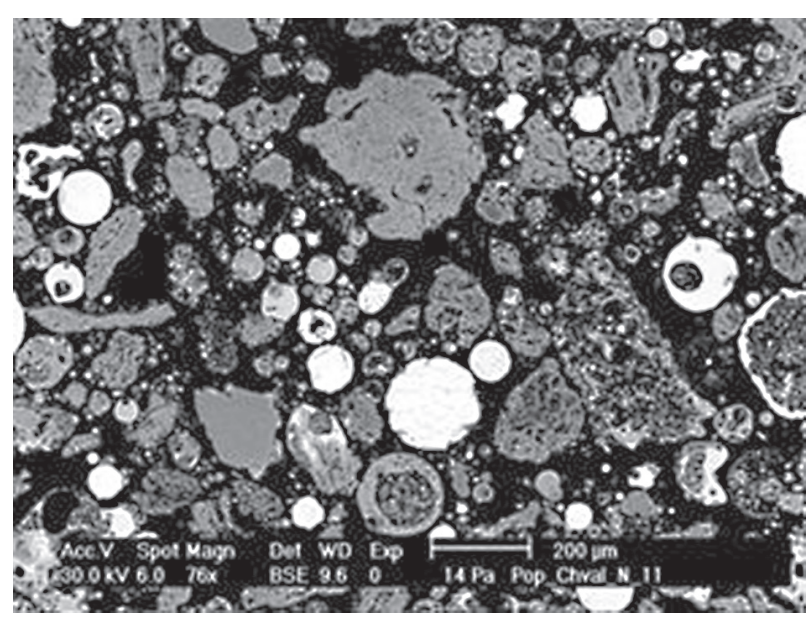

b)

Figure 8. SEM pictures of the fly ash: a) plerospheres; b) polished thin section in BSE visualization (white areas corres-pond to high iron content).

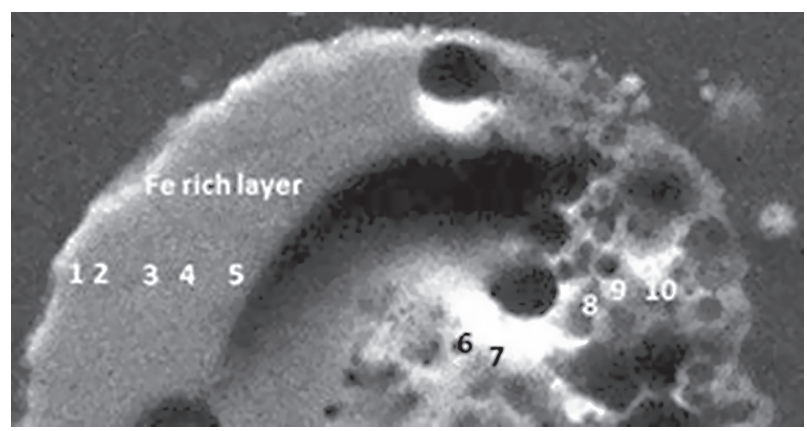

a)

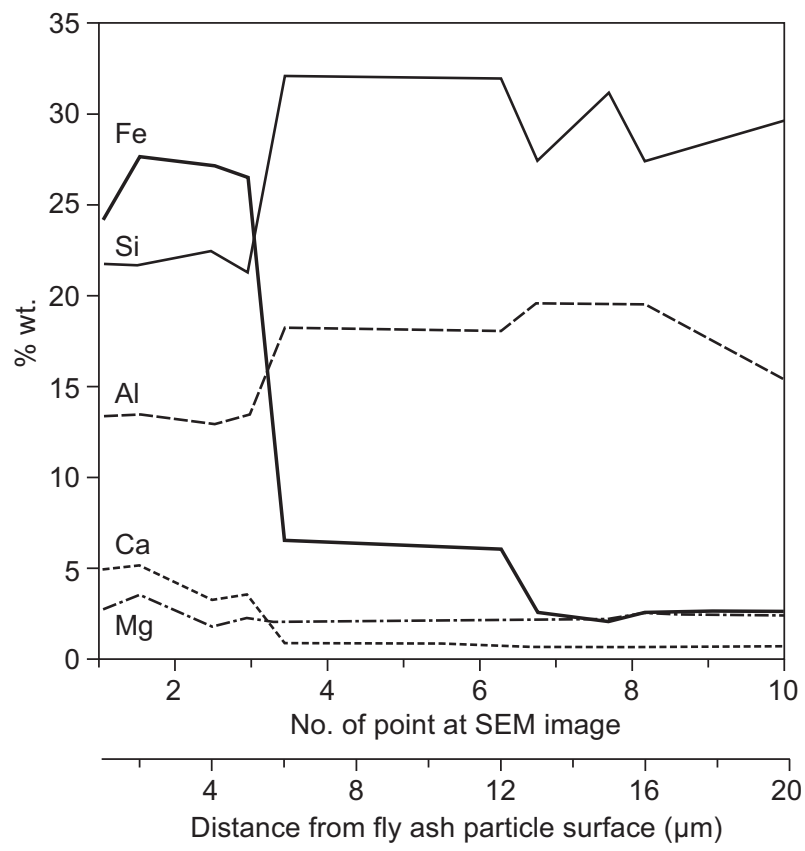

b)

Figure 9. SEM picture of a polished thin section showing both a fly ash particle (cenospheres) and a curve characterizing the dependence of the compound concentrations on the distance from them particle surface (the investigation was carried out with the aid of the point-by-point SEM/EDX analysis). with a high $\mathrm{Si}$ and $\mathrm{Al}$ content. A part of alumino-silicate melt with high iron content can often be found on the surface of fly ash particles (Figure 9). The particles are mostly compact, with a sealed porosity inside.

\section{Hydration of sulfocalcic fly ashes}

The hydration products of the sulfocalcic fly ash and those of the ordinary ones are quite different. The ordinary fly ash almost does not react with water and the hydration products are only present in mixtures with $\mathrm{Ca}(\mathrm{OH})_{2}, \mathrm{CaSO}_{4}$ or with the clinker (as this occurs in Portland-composite cements).

The mixing of the sulfocalcic fly ash with water is accompanied by water penetrating into its porous structure. A rather large water coefficient (0.8 to 1.2$)$ must be used to achieve an acceptable workability of the fly ash slurry because of the ash porosity. Bodies possessing a measurable strength (a couple of MPa approximately) can be prepared despite this fact.

At first, a quick reaction of water with $\mathrm{CaO}$ takes place during the hydration:

$$
\mathrm{CaO}+\mathrm{H}_{2} \mathrm{O} \rightarrow \mathrm{Ca}(\mathrm{OH})_{2}
$$

An expansion takes place inside the particle and fissures are generated (Figure 10) because the molar

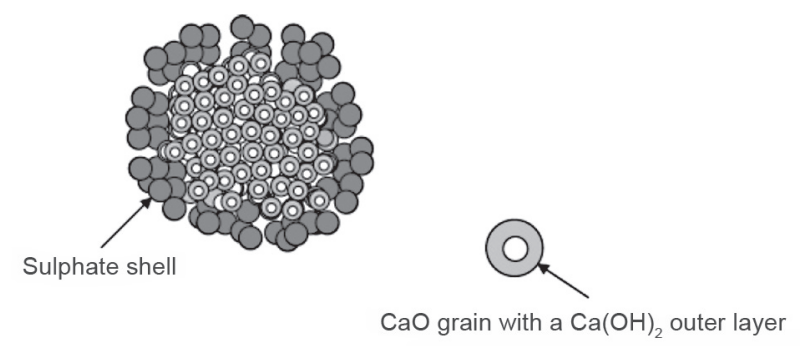

Figure 10. Conceptual representation of the beginning of sulfocalcic ash hydration [8]. 
volume of $\mathrm{Ca}(\mathrm{OH})_{2}$ is larger than that of $\mathrm{CaO}$. The $\mathrm{CaSO}_{4}$ layer cracks thus facilitating further access of water. The reaction of $\mathrm{CaO}$ with water is fast because the character of calcium oxide present in sulfocalcic fly ashes does not differ from that of the soft-burnt lime.

In the subsequent stage, $\mathrm{Ca}(\mathrm{OH})_{2}$ reacts with $\mathrm{CaSO}_{4}$ as well as with a part of aluminate-containing fly ash by giving rise to ettringite (the ettringite was termed earlier as $\left.3 \mathrm{CaO} \cdot \mathrm{Al}_{2} \mathrm{O}_{3} \cdot 3 \mathrm{CaSO}_{4} \cdot 32 \mathrm{H}_{2} \mathrm{O}\right)$ :

$$
\begin{aligned}
& \mathrm{Ca}(\mathrm{OH})_{2}+\mathrm{CaSO}_{4}+, \text {,Al part of fly ash" }+\mathrm{H}_{2} \mathrm{O} \rightarrow \\
& \rightarrow \mathrm{Ca}_{6} \mathrm{Al}_{2}\left(\mathrm{SO}_{4}\right)_{3}(\mathrm{OH})_{12} \cdot 26 \mathrm{H}_{2} \mathrm{O}
\end{aligned}
$$

This process is corroborated by the data obtained with the aid of X-ray diffraction analysis (Figure 11). The reaction is accompanied by expansion (Figure 12) that obviously finishes at the moment when all $\mathrm{Ca}(\mathrm{OH})_{2}$ formed has been converted into the ettringite [8]. In later stages, the ettringite is transformed partially into complex $\mathrm{Ca}, \mathrm{Al}$ carbonate-hydrates or into even more complex compounds as the woodfordite: $\mathrm{Ca}_{6} \mathrm{Al}_{2}\left(\mathrm{SO}_{4}, \mathrm{SiO}_{4}, \mathrm{CO}_{3}\right)_{3}(\mathrm{OH})_{12} \cdot 26 \mathrm{H}_{2} \mathrm{O}$ (Figure 11). Theoretically, also the hydration $\mathrm{CaSO}_{4} \mathrm{AII}+\mathrm{H}_{2} \mathrm{O} \rightarrow$ $\mathrm{CaSO}_{4} \cdot \mathrm{H}_{2} \mathrm{O}$ can take place. $\mathrm{CaSO}_{4}$ AII reacts slowly

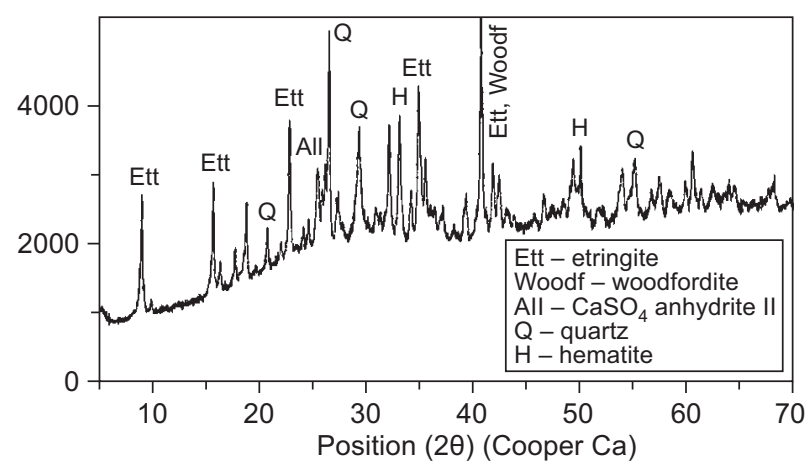

Figure 11. Diffractogram of hydrated fluidized-bed sulfocalcic fly ash after 120 days in water.

with water and this reaction is accelerated by the presence of $\mathrm{Ca}(\mathrm{OH})_{2}$ triggered by free $\mathrm{CaO}$ present in the fly ash. Nevertheless, the occurrence of $\mathrm{CaSO}_{4} \cdot \mathrm{H}_{2} \mathrm{O}$ in hydration products of the sulfo-aluminate fly ash could not be demonstrated. It seems that the ettringite is always formed preferentially.

A longer exposure of ettringite to atmospheric $\mathrm{CO}_{2}$ may also result in its decomposition into limestone, $\mathrm{CaSO}_{4} \cdot \mathrm{H}_{2} \mathrm{O}, \mathrm{Al}_{2} \mathrm{O}_{3}$ gel and water [10] as per following reaction:

$$
\begin{aligned}
& 3 \mathrm{CaO} \cdot \mathrm{Al}_{2} \mathrm{O}_{3} \cdot 3 \mathrm{CaSO}_{4} \cdot 32 \mathrm{H}_{2} \mathrm{O}+\mathrm{CO}_{2} \rightarrow \\
& \rightarrow 3 \mathrm{CaCO}_{3}+3 \mathrm{CaSO}_{4} \cdot 2 \mathrm{H}_{2} \mathrm{O}+\mathrm{Al}_{2} \mathrm{O}_{3} \cdot \mathrm{nH}_{2} \mathrm{O}+ \\
& +(26-\mathrm{n}) \mathrm{H}_{2} \mathrm{O}
\end{aligned}
$$

No hydration products of the type $\mathrm{CaCO}_{3}$ and $\mathrm{CaSO}_{4} \cdot 2 \mathrm{H}_{2} \mathrm{O}$ could be detected in the hydrated sulfocalcic fly ash.

SEM pictures of hydrated sulfo-aluminate fly ash

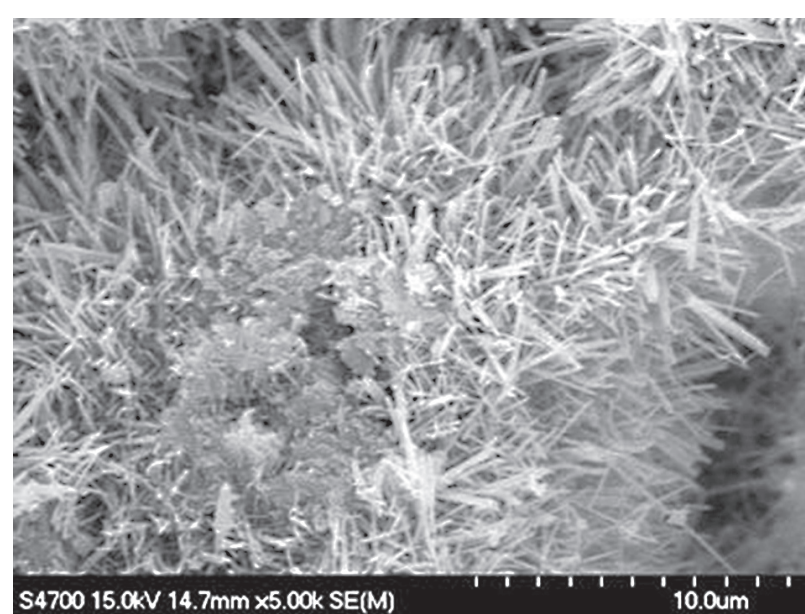

Figure 12. SEM picture of acicular ettringite in slurry of sulfocalcic fly ash (the water coefficient 1.0) kept in water for 14 days.

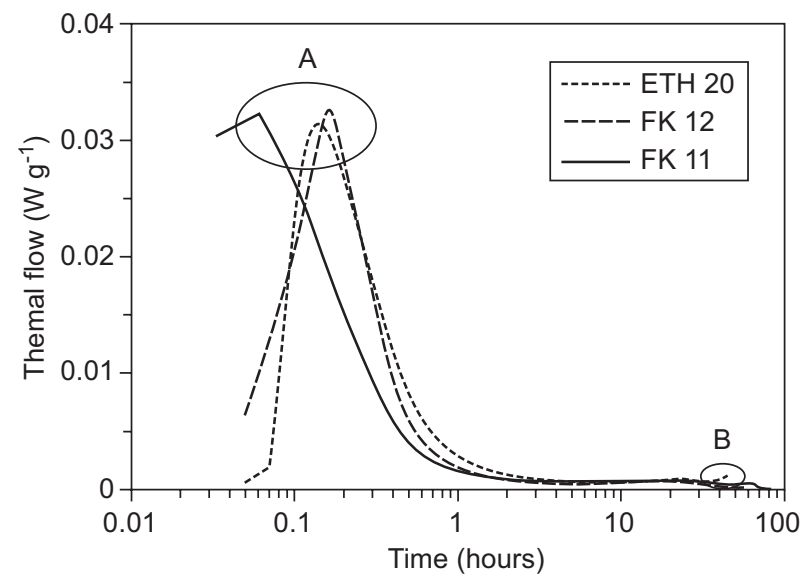

Figure 13. Curves showing the release of heat during the hydration of sulfocalcic fly ash slurries.

point to the presence of ettringite as a major hydration product (Figure 12).

The character of both initial hydration stages (a) and (b) is exothermic; they can be observed on curves showing the development in the generation of hydration heat (Figure 13).

Two regions of heat release could be identified on calorimetric curves of hydrating sulfocalcic fly ashes. The first release of heat could be observed during the first hour when the thermal phenomenon was probably due to the hydration of free $\mathrm{CaO}$ into $\mathrm{Ca}(\mathrm{OH})_{2}$ as well as to the crystallization of the ettringite (the A region),

Table 8. Values of total reaction heat determined during the hydration of sulfocalcic fly ashes.

\begin{tabular}{lcc}
\hline Sulfocalcic fly ash & $w$ & Total reaction heat $\left[\mathrm{J} \cdot \mathrm{g}^{-1}\right]$ \\
\hline FK 11 LP & 0.30 & 225 \\
FK 12 ÚP & 0.80 & 310 \\
ETH 20 & 0.80 & 150 \\
FK 12 LP & 0.50 & 370 \\
\hline
\end{tabular}


or to the formation of a $\mathrm{C}-\mathrm{S}-\mathrm{H}$ phase. The second release of heat started in the period ranging from 24 to 70 hours but, nevertheless, the heat development was not very pronounced in this case. This phenomenon may be in relation with the development of the $\mathrm{C}-\mathrm{S}-\mathrm{H}$ phase (the $\mathrm{B}$ region).

The integration of the curves characterizing the heat fluxes yielded values of the total reaction heat expressed in joules per 1 gram of fly ash (Table 8).

The values of hydration heat obtained by measurement agree qualitatively with those obtained for Canadian flue ashes by revealing an obvious relationship between the content of free $\mathrm{CaO}$ and the release of hydration heat [11].

\section{Rheological properties of fly ash slurries}

A good workability of sulfocalcic fly ashes and the achievement of an acceptable consistency require a substantially larger water coefficient as compared with

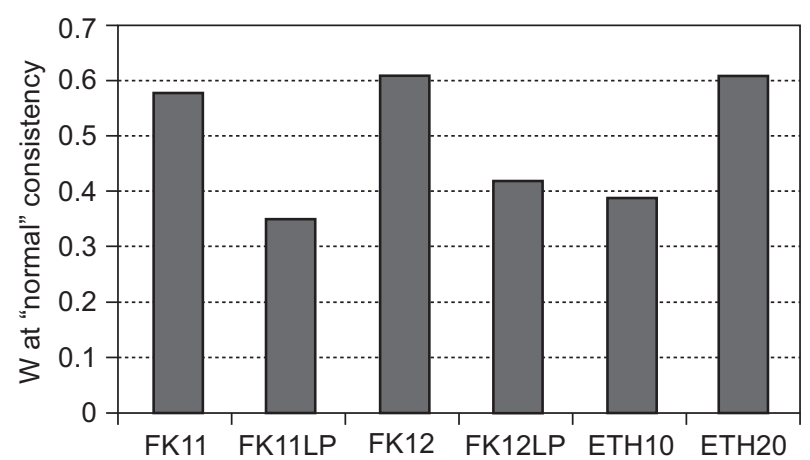

Figure 14. Rheological properties of sulfocalcic fly ash slurries ( $75 \%$ fly ash $+25 \%$ Portland cement)

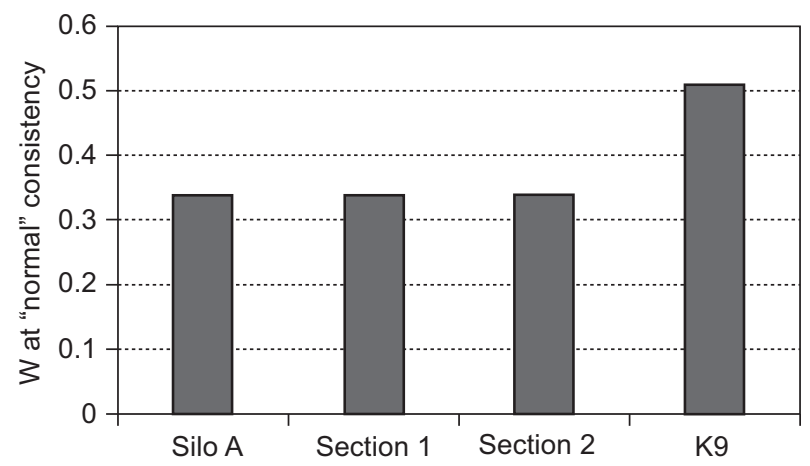

Figure 15 . Rheological properties of the ordinary fly ash (75\% fly ash $+25 \%$ Portland cement).

the slurries based on ordinary fly ashes (Figure 14 and 15). The difference in the workability of sulfocalcic fly ashes and the ordinary ones is due to the different character of their particles. Also the porosity and, hence, the water absorption of sulfocalcic fly ash particles play an important role in this case.

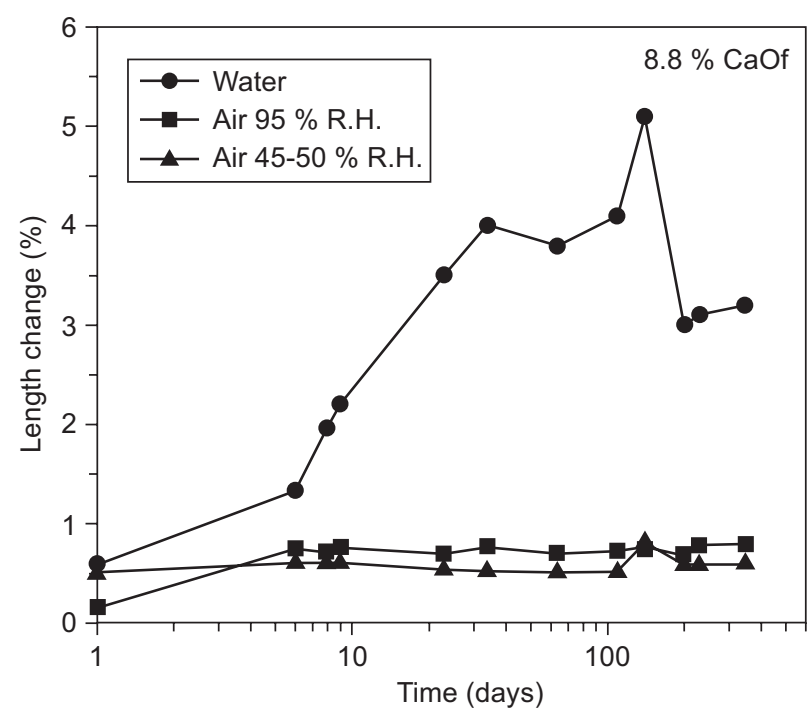

Figure 16 . Volume changes of a $4 \times 4 \times 16 \mathrm{~cm}$ body; sulfocalcic fly ash containing $8.8 \%$ free $\mathrm{CaO}$.

\section{Volume changes}

Volume changes in hardening slurries of sulfocalcic fly ashes manifest themselves by expansion. The expansion takes place particularly during their exposure to water. The volume changes drop to minimum values if

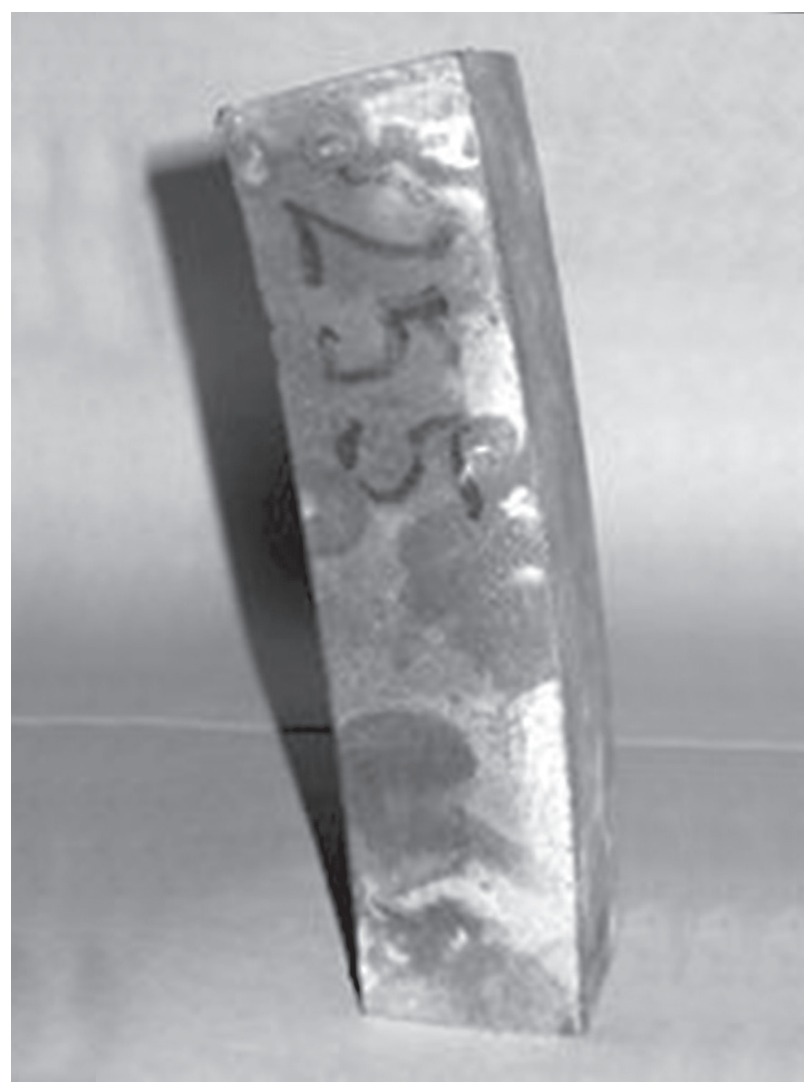

Figure 17. Deformation (induced by macroscopic expansion) of a sulfocalcic ash slurry with a water coefficient equal to 1.0, kept in water for 14 days. 
the slurries are kept in air or in a humid environment. A typical character of the expansion taking place in hardened sulfocalcic ash slurry is shown in Figure 16.

The expansion taking place in sulfocalcic ash slurries eventually results in the body destruction (Figure 17).

It is obvious that the expansion related to the ettringite formation takes place as long as there is still some $\mathrm{Ca}(\mathrm{OH})_{2}$ available (from free $\mathrm{CaO}$ ). This fact is confirmed by data supplied by the X-ray diffraction analysis: no $\mathrm{Ca}(\mathrm{OH})_{2}$ was found in sulfocalcic fly ash subjected to a long-term hydration after a detectable expansion could no longer be measured.

The reaction of alite hydration in mixtures of Portland cement with sulfocalcic fly ash is also a source of $\mathrm{Ca}(\mathrm{OH})_{2}$. This fact makes a long-term formation of the secondary expansive ettringite possible until the moment when all $\mathrm{CaSO}_{4}$ present in the sulfocalcic fly ah has been used up by the reaction. The risks associated with the use of sulfocalcic fly ash as an admixture to Portland cement are related to this fact because there is a danger that the concretes based on these mixtures would not preserve their volume stability.

\section{CONCLUSIONS}

There is much less data about sulfocalcic fly ashes in the technical literature as compared to the information on ordinary fly ashes. However, more pieces of systematic information about the composition and the reactivity of their individual constituents are needed for a potential utilization of fluidized-bed sulfocalcic fly ashes. The composition of sulfocalcic fly ashes differs from that of the ordinary ones $\left(\mathrm{CaSO}_{4}\right.$ content, free $\mathrm{CaO}$ content), the character of particles is different and also their porosity is not the same. Another difference consists in the different behavior during their hydration: the sulfocalcic fly ashes react directly with water whereas only a minimum reaction of ordinary fly ashes with water could be observed. The use of sulfocalcic fly ashes as admixtures to Portland cement is associated with a danger consisting in the formation of secondary ettringite, which results in a poor volume stability of hardened bodies. The possibility of using fluidized-bed sulfocalcic fly ashes is rather limited at present. This type of fly ashes might be used in such applications when the expansion during the hardening process would exert a negligible influence (for instance, the soil stabilization).

More research into the sulfocalcic fly ashes is necessary and desirable because of the increasing quantities of this product being rejected by coal-fired power plants.
Acknowledgment

The present work could be implemented thanks to the financial support to the FR-TI4/582 project within the TIP MPO program (Ministry of Industry \& Trade). The financial backing of the Czech company CEZ Group Energetic Products Ltd. is also greatly appreciated.

\section{REFERENCES}

1. Anthony E.J., Granatstein D.L. (2001): Sulfation phenomena in fluidized bed combustion systems. Progress in Energy and Combustion Science, 27, 215-236. doi:10.1016/S0360-1285(00)00021-6

2. Iribarne J., Iribarne A., Blondin J., Anthony E.J. (2001): Hydration of combustion ashes - a chemical and physical study, Fuel, 80, 773-784. doi:10.1016/S0016-2361(00) 00158-7

3. Wu Y., Wang Ch., Tan Y., Jia L., Anthony E.J. (2011): Characterization of ashes from a $100 \mathrm{kWth}$ pilot-scale circulating fluidized bed with oxy-fuel combustion. Applied Energy, 88, 2940-2948. doi:10.1016/j.apenergy.2011.03. 007

4. Liira M., Kirsimäe K., Kuusik R., Mõtlep R. (2009): Transformation of calcareous oil-shale circulating fluidizedbed combustion boiler ashes under wet conditions. Fuel, 88, 712-718. doi:10.1016/j.fuel.2008.08.012

5. Yoffe O., Nathan Y., Wolfarth A., Cohen S., Shoval S. (2002): The chemistry and mineralogy of the Negev oil shale ashes. Fuel, 81, 1101-1117. doi:10.1016/S00162361(02)00021-2

6. Roy D.M., Luke K., Diamond S. (1984): Characterization of fly ash and its reaction in concrete. MRS Proceedings, 43, 3-20. doi:10.1557/PROC-43-3

7. Lutze D., vom Berg W. (2010). Handbook on fly ash in concrete: Principles of production and use. 2 nd ed. Verlag Bau+Technik: Düsseldorf.

8. Wu Y., Anthony E.J., Jia L. (2004): Steam hydration of $\mathrm{CFBC}$ ash and the effect of hydration conditions on reactivation. Fuel, 83, 1357-1370. doi:10.1016/j. fuel.2004. 01.006

9. Wang J., Wu Y., Anthony E.J. (2005): The Hydration Behavior of Partially Sulfated Fluidized Bed Combustor Sorbent. Industrial \& Engineering Chemistry Research, 44, 8199-8204. doi:10.1021/ie0507124

10.Nishikawa T., Suzuki K., Ito S. (1992): Decomposition of synthesized ettringite by carbonation. Cement and Concrete Research, 19, 6-14. doi:10.1016/0008-8846(92)90130-N

11. Anthony E.J., Jia L., Caris M., Preto F., Burwell S. (1999): An examination of the exothermic nature of fluidized bed combustion (FBC) residues. Waste Management, 19, 293305. doi:10.1016/S0956-053X(99)00136-1 